the soliloquy. Shakespeare uses this technique most powerfully in perhaps his greatest history play, Richard III. Here, Dillon argues, the drama's narrative and Richard's characterization are both shaped by such 'close-ups'. While 'the soliloquy can change in status and effect very considerably over the course of a play' (87), the rhetorical event of a direct address to the audience represents Richard's 'most characteristic mode of acting' (86). Like the distanced pageantry of Henry VIII, moreover, such directness and intimacy provoke the audience to interrogate the actions on stage. The soliloquy 'closeup' 'point [s] up a personal dimension in the lives of those who make history, which in turn helps to problematize the perception of history that the audience forms from the plays' (96).

Another key facet of Shakespeare's skill in dramatic staging highlighted by this study is his adroit use of props, exemplified in his last history play Henry VIII. The introductory stage direction 'A cloth throughout the play', as Dillon notes, 'implies that the chair of state, with its canopy, is on stage for every scene' (111). Thus Shakespeare is able to imbue the prop with a certain kingly significance (the play opens with the monarch seated on his 'throne'), establishing in the minds of the audience an aura of puissance around the object. Consequently, the dramatist undercuts this aura by seating the 'butcher's cur', Cardinal Wolsey, in the very same chair later on in the first act. Ironizing the symbolism surrounding royal objects, such an example also highlights Shakespeare's ability to utilize theatrical objects as well as rhetoric in the composition and staging of his history plays.

Christina M. Fitzgerald and John T. Sebastian (gen. eds). The Broadview Anthology of Medieval Drama. Peterborough, ON: Broadview Press, 2013. Pp xiii, 566.

Chester N. Scoville Early Theatre 16.1 (2013), 183-5

University of Toronto doi: http://dx.doi.org/10.12745/et.16.1.12

This new book represents the first comprehensive anthology of its kind since Greg Walker's Medieval Drama (Oxford, 2000). More importantly, it is the first such anthology in nearly forty years, since David Bevington's classic Medieval Drama (Boston, 1975), to rethink how to present these texts 
accessibly to undergraduates. As such, it represents a fresh introduction to the field and provides teachers and students with a new standard resource that successfully meets the needs of the contemporary classroom.

Many of the features of this text will be immediately recognizable to those familiar with Bevington or Walker, yet the new Broadview Anthology makes numerous choices that set it apart. The general shape of the book is familiar enough: beginning with such texts as Hrosvitha's Abraham and the Quem Quaeritis trope of the Regularis Concordia of Aethelwold, it proceeds through the explosion of twelfth-century drama (including the Play of Adam and the Fleury Herod), devoting much of its middle section to the four great Middle English play collections (York, Towneley, N-Town, and Chester) and moving on via some familiar morality and miracle plays (Mankind, Everyman, The Play of the Sacrament) to conclude with such comedies and interludes as Youth, Gammer Gurton's Needle, and Heywood's Play of the Weather.

Within that familiar shape, however, the Broadview text is both innovative and up to date. Most obviously, it is the first comprehensive classroom anthology finally to do away with the artificial play cycle, in which individual episodes from the York, Towneley, N-Town, and Chester plays are spliced together to create the illusion of a lost ur-text: a practice that was standard in such anthologies at least since Adams's Chief Pre-Shakespearean Dramas (1924). Because the theory of the normative Corpus Christi cycle has now been largely abandoned, it is well past time that standard classroom texts stopped trying to reflect it; for that reason alone, Fitzgerald and Sebastian have done the field a positive service and earned their text's place as preferential choice for undergraduate instructors.

Once freed from the ur-cycle fallacy, the plays can be arranged in newly illustrative and interesting ways. For example, the Ordo Paginarum and the Mercers' Indenture frame the anthology's selection of York plays, thereby emphasizing their connection to their city of origin and the physical conditions attendant thereto. Passages from the Douai bible accompany selected Towneley and Chester plays, showcasing their elaboration upon the sparse biblical text. The Mary Play (complete) and The Nativity illustrate the textual complexity of the N-Town collection. The anthology also presents, uniquely, a significant selection from such non-English texts as the Cornish Ordinalia and the Welsh Three Kings of Cologne; notable too is a selection of disguisings and mummings by John Lydgate. In preparing their texts for undergraduates, the editors have modernized the spelling and provided appropriate and useful apparatus: each selection is accompanied by a brief but helpful 
introduction, and the plays are given marginal glosses and explanatory footnotes, informative but not overwhelming in scope and detail.

If there is a caveat regarding this anthology, then it must concern the omission of specific materials. For example, from the Macro plays the book includes only Mankind along with the diagram from The Castle of Perseverance (oddly stranded without its play), and nothing at all from the Digby plays. Some of the omissions from York, Towneley, N-Town, and Chester are puzzling. Why, for example, does the book include no fewer than four shepherds' plays while omitting any play of Abraham and Isaac? To be fair, the book's accompanying website promises to post further texts as they are edited, yet at the time of this writing that part of the site remains empty of content; no doubt this will change over time.

One may always quibble with matters of selection and omission in anthologies. More important than those specifics is the way in which the text as a whole reflects both the state of the field and the needs of the classroom, and in this regard Fitzgerald and Sebastian, with their team of editors, have made a landmark contribution. The Broadview Anthology gives instructors a wealth of material to choose from, all excellently edited and presented. It is both solid and up-to-date in scholarship, and friendly and accessible to students. Its new approach to the presentation of texts and its thought-provoking selection of materials make it a most welcome addition to the field; it ought to remain the standard undergraduate text for many years to come.

\section{Charles R. Forker (ed.). The Troublesome Reign of John, King of Eng- land. Manchester: Manchester University Press, 2011. Pp xxviii, 379.}

Karen Oberer

Early Theatre 16.1 (2013), 185-8

Concordia University

doi: http://dx.doi.org/10.12745/et.16.1.13

Over thirty years have passed since John Sider's edition of The Troublesome Reign appeared in print, the product of his 1971 University of Notre Dame dissertation project. Charles Forker's recent edition therefore represents a welcome and much needed reconsideration of the play's text and historical context. Following Scott McMillan and Sally-Beth MacLean's The Queen's Men and Their Plays (Cambridge, 1998) there has been a resurgence of interest in 